ОВчИННИКОВ Александр Викторович - кандидат исторических наук; научный сотрудник лаборатории трансдисциплинарных исследований познания, языка и социальных практик философского факультета Национального исследовательского Томского государственного университета (634050, Россия, г. Томск, пр-кт Ленина, 36; ovchinnikov8_831@mail.ru)

\title{
«ВЕЛИКИЙ НЕЗНАКОМЕЦ» И УРБАНИЗАЦИОННЫЙ ФРОНТИР (к проблеме социально-психологических оснований исторической «травмы 1552 года»)
}

\begin{abstract}
Аннотация. Ставится проблема комплексного изучения этноориентированных мифов о прошлом. На примере представлений о захвате Казани войсками Ивана IV в 1552 г. констатируется важность анализа социально-психологических оснований мифа. Проводится компаративистское исследование основных «конструкторов» и «потребителей» мифа исторической «травмы 1552 г.»: академических учреждений Казани и уникального своей типичностью пригородного сельского Пестречинского района Татарстана. Выявлены общие элементы социальной реальности, специфика которых обусловлена урбанизационными процессами и «фронтирной травмой».
\end{abstract}

Ключевые слова: “миф 1552 г.», историческая травма, урбанизация, Пестречинский район, «фронтирная травма».

П редставленная статья является логическим продолжением статьи, опубликованной в 4 номере данного журнала за 2020 г. (Овчинников, Ершова 2020). Главная идея публикации заключалась в попытке комплексного изучения современных российских региональных этноориентированных мифов о прошлом. В настоящей статье это положение получит дальнейшее развитие. Дело в том, что простая логическая деконструкция содержания мифа, фиксация ошибок, подтасовок и недоговоренностей (Овчинников 2009б) не позволяют понять причин живучести мифа, его укоренённости даже в академических текстах. Если миф «не умирает», значит, он кому-то нужен, т.е. выполняет важнейшую функцию объединения социальных групп вокруг сомнительных с точки зрения логики повествований. Кейс представлений о захвате Казани войсками Ивана IV в 1552 г. интересен тем, что позволяет увидеть социальнополитические и психологические основы мифа, которые, в свою очередь, так или иначе связаны с урбанизационным фронтиром последних десятилетий и явно соотносятся с психологической «фронтирной» травмой (Васина, Овчинников 2019).

Костяк академических учреждений Татарстана и местной политической элиты (т.е. основных акторов актуализации «мифа 1552 г.») - выходцы из сельской местности, горожане в первом поколении (Сагитова 2019: 143), и поэтому конструирование исторической «травмы 1552 г.» на символическом уровне может означать стремление к «освобождению» политического пространства от сил, олицетворяющих затрудненность доступа ко всевозможным благам и ресурсам (Федеральный центр - «наследник» Ивана IV, а Татарстан - покоренной в 1552 г. Казани и Казанского ханства в целом) (Овчинников 2019). Исходя из этого может быть создана комплексная социально-историческая модель анализа этноориентированных мифов.

В случае аналитической модели «мифа 1552 г.» хорошо известно содержание его «исторической части» (Овчинников 2018a), тогда как социально-психологическая основа нуждается в конкретизации. Здесь мы оказываемся в про- 
блемном поле изучения «великого незнакомца» или «неудобного класса» (по Т. Шанину), т.е. крестьянского и посткрестьянского мира в сложных перипетиях его, в том числе урбанизационных, трансформаций (Великий... 1992; Шанин 2019). Впервые в литературе будет представлен опыт компаративистского исследования основных вех истории развития академического сообщества г. Казани и социума пригородного по отношению к Казани уникального своей типичностью Пестречинского района Татарстана. Такой формат анализа, как мне кажется, позволит изучить часто скрытую от посторонних глаз сложную палитру социально-политических отношений, в которых миф является лишь одним из множества взаимосвязанных элементов, изъятие которого (критическая деконструкция), расшатывает всю систему социальных договоренностей, и потому миф оказывается более выгоден, нежели логически безупречные научные построения о прошлом.

Современный Татарстан - посттрадиционное общество. О деревне ностальгирует нынешний глава региона Р.Н. Минниханов (род. в 1957 г. в селе Новый Арыш Рыбнослободского района ТАССР). 30 ноября 2018 г. на форуме Всемирного Конгресса татар он говорил, что «деревня - наша основа» и искренне признавался, что ему «совсем не хотелось переезжать в Казань, просто учеба заставила. Честно, мне нравилось жить в деревне, и сейчас, приезжая туда, мне хочется сделать что-то для этих людей. Возможно, мой переезд в Казань был главной ошибкой в моей жизни...». Вместе с тем, кроме «нравственных», деревенское подворье служит образцом еще для политических, социальных и экономических начал, которые современной политологией объединяются в понятие «авторитарного государства». Неудивительно, что организация управления экономикой в Татарстане напоминает «автаркичное патриархальное хозяйство», в котором «ключевые посты заняты родственниками или проверенными людьми» (Салагаев, Сергеев, Лучшева 2009: 28).

Сельское происхождение гуманитариев Волго-Уралья, отразившееся на специфике их текстов, отмечал французский исследователь Ле Торривеллек (Ле Торривеллек 2011). О большой доли бывших сельчан среди работников научных и культурных учреждений Казани пишет М.З. Закиев (род. в 1928 г. в деревне Зайпы Ютазинского (ныне Бавлинского) района Татарской АССР), многие годы являвшийся административным руководителем всей академической гуманитарной науки ТАССР и Татарстана. О многом говорит опубликованный в казанском журнале «Эхо веков» внушительный список учёных, вышедших изсёл колхоза «Коммуна» Буинского района Татарстана. Интересно признание научного сотрудника Института истории им. Ш. Марджани Р. Галляма (родился в 1960 г. в Арском районе ТАССР), сделанное им на конференции, посвящённой юбилею известного казанского учёного С.Х. Алишева (1929-2015, род. в деревне Щербень ныне Аксубаевского района Татарстана): «свои университеты мы прошли в деревне» (перевод с татарского).

Современные политико-бюрократические контуры Татарстан начал обретать еще в брежневское время в годы продолжительного правления Первого секретаря Татарского Обкома КПСС Фикрята Табеева (1960-1979, 1928-2015, род. в селе Азеево Рязанской области). Тогда же стали увеличиваться ряды местной гуманитарной интеллигенции, имевшей в основном сельское происхождение и сосредотачивавшейся в создаваемых советской властью местных научных и высших учебных заведениях.

Между политической и интеллектуальной региональными элитами устанавливались патрон-клиентские отношения. Так, во время правления Ф.А. Табеева лидером местной академической гуманитарной науки был директор Института языка, литературы и истории Казанского филиала 
Академии наук СССР и ректор Казанского государственного педагогического института, доктор филологических наук М.З. Закиев. Он многое сделал для формирования татарской гуманитарной интеллигенции, в том числе и авторов национальных историй. Ф.А. Табеева и М.З. Закиева связывали личная дружба и годы совместного обучения в Казанском государственном университете.

В работах М.З. Закиева прямо говорится о том, что во времена Ф.А. Табеева в Татарском Обкоме КПСС происходили встречи с историками, где обсуждались «вопросы происхождения и развития татарского народа». Представители номенклатуры могли поддержать или отвергнуть предлагаемую точку зрения (понятно, что в зависимости от идеологических, а не научных соображений). Получившая «высокое» признание историческая версия, например, происхождения татар в дальнейшем становилась объектом «разъяснительной работы среди народа». Вести такую работу «Обком КПСС регулярно требовал от татарских историков, писателей и журналистов».

В 1990-е гг. с обретением Татарстаном суверенного статуса отношения местных властей и ученых мало изменились. После ухода Ф.А. Табеева с поста руководителя ТАССР пошатнулись позиции его протеже М.З. Закиева. Против него в недрах возглавляемого им академического института возникла оппозиция в лице относительно молодых историков и археологов (среди них следует особо отметить одного из лидеров татарского национального движения, доктора исторических наук Д.М. Исхакова (род. в 1952 г. в поселке Шемордан Сабинского района ТАССР). Конфликт решался политическими властями Татарстана, в результате чего в составе региональной Академии наук появился самостоятельный Институт истории им. Ш. Марджани. Его возглавил бывший идеолог Татарского обкома КПСС Рафаэль Хакимов (род. в 1947 г. в г. Казани), физик по образованию и сын известного татарского поэта Сибгата Хакима (род. в 1911 г. в д. Кулле-Кими ныне Атнинского района Татарстана) (в 2010 г. Рафаэль Сибгатович защитил докторскую диссертацию по исторической специальности, вызвавшую, впрочем, немало нареканий) (Овчинников 2009а).

Как в свое время М.З. Закиев, Р.С. Хакимов входит в «цитоплазму» региональной политической элиты, имеющей явные традиционно-патриархальные черты. Вместе с высшими руководителями Татарстана он проживает в элитной деревне Боровое Матюшино под Казанью. Интересен рассказ Рафаэля Сибгатовича о праздновании Нового года: «У нас традиционно в деревне в Боровом Матюшино Новый год открывает Минтимер Шаймиев (Президент Татарстана до 2010 г., род. в 1937 г. в деревне Аняково нынешнего Актанышского района Татарстана - А.О.). Так что все соберемся и под его началом будем петьтанцевать». Неосторожное высказывание Р.С. Хакимова, как мне кажется, обрисовывает контуры типичного для традиционных обществ тайного мужского союза со своими ритуалами, инициациями, особым языком и т.д. Он представляет собой сердцевину имеющей сельское происхождение политической элиты, именно здесь принимаются важнейшие решения. Р.С. Хакимов является посредником-куратором между властями Татарстана и местным академическим сообществом.

Таким образом, в годы горбачевской Перестройки и позднее в руководящих структурах академических гуманитарных учреждений Казани происходил передел власти. Типологически схожие процессы наблюдались и в организациях сельского Пестречинского района, в которых в конце 1980-х - начале 1990-х гг. высшие должности замещались новыми лицами едва ли не каждый год (Овчинников 2018б: 294). 
В этот же период под лозунгами идеологической свободы и поиска ранее запретных исторических истин происходит передел власти в корпорациях историков. Так, в Татарстане вспыхивает борьба между «татаристами» и «булгаристами», в срезе местной Академии наук на поверку оказавшейся борьбой рвущейся к административной власти «молодых татаристов» (Исхаков Д.М., Измайлов И.И. (род. в 1960 г. в п. Сеймчан Среднеканского района Магаданской области) и др.) со «стариками- булгаристами» (например, М.3. Закиевым). В эти же «нестабильные» годы под прикрытием «разрешенного исторического новаторства» и влиятельных покровителей смог «закрепиться» в должности заведующего кафедрой Казанского государственного педагогического института (затем университета) 3.3. Мифтахов (род. в 1938 г. деревне Старое Килимово Буздякского района Башкирской АССР), печально известный текстами в жанре «фолк-хистори».

К концу 1990-х гг. отношения внутри политической элиты стабилизируются и на примере Пестречинского района можно наблюдать процесс сращивания власти и собственности, когда чиновники, пользуясь служебным положением и открывшимися возможностями рынка, начинают ставить под свой личный контроль и контроль родственников экономическую жизнь района (так, в «нужных руках» оказываются гастроном, другие магазины, бывшие административные здания и, особенно, земельные участки).

На стене просторного холла здания администрации Пестречинского района висит галерея портретов руководителей района. Молодых красноармейцев с наивным взглядом и в непритязательной одежде постепенно сменяют важные бюрократы в деловых костюмах. Цепочка образов отражает эволюцию советской номенклатуры, осуществившей сначала коллективную, а затем и частную приватизацию ресурсов страны. Хотя красноармеец и не похож на «поздних глав», тем не менее, именно он является их «прародителем».

С кон. 1990-х - нач. 2000-х гг. стабилизируется ситуация и в корпорациях историков г. Казани. Ученые советского формата, жившие на скромную зарплату и мечтавшие об академической карьере, венцом которой была бы персональная дача, превращаются в ученых-бизнесменов, «этнических дельцов». Как было сказано выше, борьба между «татаристами» и «булгаристами» закончилась появлением Института истории им. Ш. Марджани АН РТ. Его конкурентом стал исторический факультет Казанского государственного университета им. В.И. Ульянова-Ленина во главе с И.Р. Тагировым (род. в 1936 г. с. Старое Шугурово Татарской АССР). Играя на противоречиях между двумя корпорациями, политическая элита Татарстана смогла мобилизовать историков на конструирование региональной идеологии.

Утверждение и упрочение в нач. 2000-х гг. новой иерархии внутривластных отношений и стремление обладающих административным ресурсом политических элит к обогащению обусловили схожие процессы и в корпорациях историков. Так, с 2015 г. археологическая экспертиза при строительстве стала обязательной, и это привело к тому, что через пять лет на одной из встреч с Президентом Татарстана Р.Н. Миннихановым предприниматели прямо пожаловались на чрезвычайно длительную и дорогостоящую процедуру историкокультурной экспертизы (даже капитальный ремонт фундаментов действующих заводов формально требовал внимания археологов, при этом на начало 2020 г. цена вопроса, судя по признаниям бизнесменов, варьировала от 200 до 700 тыс. рублей). Даже сам Р.Н. Минниханов назвал, правда, шутя, проведение историко-культурной экспертизы строящихся объектов «бизнесом». В процессе обсуждения проблемы выяснилось, что на период начала 2020 г. в Татарстане археологические работы могут выполнять 15 организаций. Они так или иначе 
контролируются руководством Института археологии АН РТ, сотрудники данного Института часто «по совместительству» являются и сотрудниками этих 15 организаций. Скорее всего, такой удачный бизнес может быть возможен только при условии патронажа со стороны региональных властей, ответной же «услугой» археологов является идеологическое и ритуально-научное обслуживание мега-проектов, в которых заинтересованы сами покровители (так, Р.Н. Минниханов отверг возможность участия в историко-культурной экспертизе «нетатарстанских» археологов).

Показателен получивший огласку в прессе случай с экспертизой строительства Высокоскоростной магистрали в окрестностях Казани. Директор Института археологии им. А.Х. Халикова (1929-1994, род. в д. Курманаево Нурлатского района ТАССР) АН РТ А.Г. Ситдиков (род. в 1973 г. в с. Большая Атня Атнинского района ТАССР) и его заместитель Ф.Ш. Хузин (род. в 1951 г. в д. Карманово Заинского района ТАССР) до начала экспертизы нашли нужным поднять в местных СМИ «шум» о том, что находки в районе строительства обязательно должны быть, а это автоматически вело к заключению договоров на как можно скорейшее исследование памятников, иначе строители понесли бы огромные потери от «простоя». Однако непосредственное проводившееся подчиненными А.Г. Ситдикова и Ф.Ш. Хузина обследование территории будущей магистрали не принесло результатов - ни один памятник, вопреки прежним заявлениям, обнаружен не был.

«Лакомым куском» является участие в научном сопровождении республиканского уровня мега-проектов, например, «1000-летия» Казани (фактически обосновано Ф.Ш. Хузиным и А.Г. Ситдиковым) или «возрождения» архитектурно-археологических комплексов Болгара и Свияжска. Только в 2017 г. проводившиеся в основном силами Института археологии АН РТ в Болгаре и Свияжске археологические изыскания обошлись казне в 128,3 млн рублей.

Вновь обратимся к материалам Пестречинского района. Показательна история сотрудника местного военкомата М. Параллельно работе с призывниками он открыл частный магазин по продаже товаров для ремонта. Проходя мимо магазина, можно было часто видеть (до)призывников, занятых разными связанными с бизнесом М. делами (от кладки стены пристроя до уборки снега). Чиновник-предприниматель знал границы собственной власти над призывниками и их родителями. Помню, как в 2001 г. будучи студентом первого курса истфака и проходя медкомиссию в стенах военкомата, вместе с другими призывниками я оказался в одной комнате с М. Он резко и неожиданно разразился матом, констатируя что мы «никто», и «для того, чтобы не убирать вилами навоз» и стать «настоящими людьми и мужиками» (последние две категории он, почему-то, разделял) нам нужно обязательно отслужить в армии. Моя мама рассказывала, что прямо в военкомате он избил сына её подруги Н., работавшей уборщицей и потому в глазах М. имевшей низкий социальный статус. Мать избитого сына приходила жаловаться в тот же военкомат, но «те лишь смеялись».

М. интуитивно понял, какие возможности появились в 1990-х гг. с легализацией рыночных отношений, и что государственная должность может стать решающим фактором его обогащения. Посещения Пестречинского райвоенкомата и наблюдения за его сотрудниками привели меня к мысли о банальности причин затяжного характера вооруженных конфликтов в позднесоветское и постсоветское время. Например, 10 лет войны в Афганистане можно объяснить в том числе и мощным «военкоматовским» лобби, получавшим серьезные доходы от родственников 18-летних призывников, не желавших исполнять «интернациональный долг». «Расцвет деятельности» М. пришелся 
на 1990-е гг, когда матери и отцы готовы были отдать последнее, только бы их дети не оказались в Чечне. Видимо, у М. сложилась типичная для современной российской элиты (а он относится к её низшему звену) «философия жизни», в рамках которой значимы удовольствия и интересы своей семьи и близких друзей. Все, кто находятся за пределами этого круга воспринимаются как серая масса, на которую распространяются совершенно иные нормы взаимоотношений.

Как и в случае с «горячими точками» и районным военкоматом, в этнонационализме и мифологизации истории заинтересованы корпорации казанских историков, т.к. подобные формы репрезентации прошлого обеспечивают взаимовыгодные коммуникации с политическими элитами и, следовательно, конвертацию символического капитала в реальные жизненные блага. Корпоративная замкнутость обуславливает невнимание к интересам тех, кто вынужден «потреблять» произведенный миф, и отсутствие, по крайней мере, видимых рефлексий о собственной моральной ответственности. Так, с 2010 г. татарстанские историки и археологи в массовом порядке участвуют в научном обосновании «возрождения» архитектурно-археологических памятников Болгара и Свияжска (Овчинников 2017). На этот мега-проект собирались деньги практически со всех организаций Татарстана (в том числе, детских домов), и судя по публикациям в СМИ, не всегда добровольно. Знать это и все равно быть причастным к конструированию мифа возможно только в условиях социальной корпоративной дискретности и семейной замкнутости, которые, в свою очередь, являются наследием традиционного крестьянского социума (В мае 2018 г. я случайно оказался в одном казанском автобусе вместе с активным участником упоминаемых выше мега-проектов историком и археологом $\mathrm{X}$. и его женой. Супружеская пара оживленно обсуждала с еще одной женщиной (невесткой?) покупку мебели в коттедж. Из разговора я понял, что речь идет о более чем сотни тысяч рублей и это только начало обустройства второго этажа. Также обсуждалась поездка внука (?) в лагерь «Орленок», которую, исходя из разговора, должен был оплатить дед (?), т.е. Х. Можно предположить, что подобные «семейные хлопоты» являются определяющими мировоззрения $\mathrm{X}$ и именно они сублимируют моральную ответственность по отношению к «чужим»).

Основным элементом социальной реальности академического сообщества Казани и Пестречинского района являются дискретные профессиональные объединения (т.н. «организации»), по своим основным параметрам напоминающие крестьянские общины и в эволюционном отношении выступающие их прямыми наследниками (Овчинников 2016б). В обоих случаях большую роль играют родственные связи. В конце февраля 2020 г. я присутствовал на встрече выпускников 2000 г. Пестречинской средней школы № 1. Судя по типичным для таких застолий разговорам, примерно половина моих одноклассников в профессиональном плане пошла по стопам родителей, а проще говоря, в свое время родители устроили их «по знакомству» на уже давно присмотренные места. Повинуясь ностальгическим настроениям, я посетил родную школу, и каково же было моё удивление, когда я увидел, что моя первая учительница за прошедшие 20 с лишним лет ничуть на постарела, а, наоборот, даже помолодела и работает все в том же кабинете... Оказалось, передо мной стояла её дочь... В 2000-е гг. среди сотрудников небольшого исторического факультета Казанского государственного университета только при первом приближении можно было насчитать шесть родственных кланов и династий (Овчинников 2016a).

Эти постобщины в равной степени эксплуатируются государством: в 
Пестречинском районе сельчан мобилизуют на бесплатные субботники и воскресники, сборы пожертвований и самообложение, организацию выборов (Овчинников 2018б: 298-300); «академиков» же привлекают к конструированию региональной идеологии, научному обоснованию мега-проектов, критике идеологических противников в соседних регионах и в Федеральном Центре. Частью этой «символической ренты» является поддержание мифа исторической травмы 1552 г. Как селяне не могут уклониться от формально добровольных работ и пожертвований, так и ученые не могут недодать требуемого объема «символической ренты» (О зависимости казанских ученых корпораций«постобщин» от местных властей свидетельствует случай с попыткой реорганизации Института истории им. Ш. Марджани АН РТ в мае-июне 2020 г. (Овчинников 2020). Тогда главным арбитром в межклановой борьбе ученых выступил Аппарат Президента РТ, решения которого были исполнены беспрекословно).

Комплексный анализ кейса исторической травмы 1552 г. показал, что этноориентированные мифы о прошлом продуктивно изучать в широкой перспективе социально-психологических трансформаций «великого незнакомца», его настороженного отношения к пока еще плохо понятным индустриальным и постиндустриальным реалиям, и стремления сохранить привычную общественную самоорганизацию и соответствующее поведение.

Статья публикуется при поддержке Школы молодого этнополитолога в Республике Башкортостан (грант Фонда президентских грантов 19-2-022447).

\section{Список литературы}

Васина В.В., Овчинников А.В. 2019. Проблема исторической детравматизации этнического сознания (постановка проблемы) - «Прошлое»: теория и практика (де)конструирования в научном и политическом дискурсах: Материалы Всероссийской с международным участием научно-практической конференции, Казань, 22-23 ноября 2019 г. / Отв. редактор А.В. Овчинников. Казань: Изд-во «Познание» Казанского инновационного университета. С. 341-347.

Великий незнакомец. Крестьяне и фермеры в современном мире (сост. Т. Шанин). 1992. М.: Издательская группа «Прогресс» - Прогресс-Академия, 1992. 426 с.;

Ле Торривеллек К. 2011. Этнос в истории историков: национальная историография Волго-Уральских народов (1956-1970 годы) - Волго-Уральский регион в имперском пространстве: XVIII-XX вв. / под ред. Наганава Норихиро, Усмановой Д.М., Хамамото Мами. М: Вост. лит. С. 308-342

Овчинников А. В. 2009а. 90-е годы закончились? (по поводу защиты Р. С. Хакимовым докторской диссертации) - Звезда Поволжья. № 36 (487). 24-30 сентября. С. 3.

Овчинников А.В. 2009б. Дешевая историография (ответ И.Л. Измайлову). Части 1, 2, 3. 9.09.2009, 23.09.2009, 6.11.2009. Доступ: https://ruskline.ru/analitika/2009/09/09/deshevaya_istoriografiya, https://ruskline.ru/ analitika/2009/09/23/deshevaya_istoriografiya, https://ruskline.ru/analitika/2009/11/06/deshevaya_istoriografiya (проверено 1.12.2020).

Овчинников А.В. 2016а. Классический университет в современной России: «эгоистичные интеллектуалы и коллективистские идеологии...»-Классический университет: история и современность: материалы Всероссийской с международным участием научно-практической конференции, посвященной 85-летию 
Удмуртского государственного университета; Ижевск, 3-4 февраля 2016 г. / отв. ред. и сост. В.В. Пузанов, Д.В. Репников. Ижевск: Издательский центр «Удмуртский университет». С. 98-108.

Овчинников А.В. 2016б. Концепт «Постбщина»: возможности анализа социокультурного пространства гуманитарного научного сообщества Исторический формат. № 1. С. 325-332.

Овчинников А.В. 2017. «Возрождение» Болгара и Свияжска - новейший опыт конструирования исторической памяти - Вестник Пермского университета. История. Вып. 4(39). С. 192-201.

Овчинников А.В. 2018а. Репрезентация исторической «травмы 1552 года» в материалах Деловой электронной газеты Татарстана «БИЗНЕС Online» Историческая память: травмы прошлого, противоречия настоящего, перспективы будущего / под ред. В.Н. Сырова. [Текст]: Сборник статей по итогам всероссийской научной конференции. Саратов: ИЦ «Наука», 2018.С. 161-167.

Овчинников А.В. 2018б. Современная история Пестречинского района Татарстана в дискурсе социально-культурной антропологии (опыт исследования) - Развитие регионоведческих исследований в Российской Федерации: особенности и основные направления: сборник статей Всероссийской научнопрактической конференции (г. Казань, 7 декабря 2018 г.) / Институт татарской энциклопедии и регионоведения АН РТ / отв. ред.: Р.В. Шайдуллин, Л.М. Айнутдинова. Казань. С. 289-305. С. 294.

Овчинников А.В. 2019. Личная психологическая и «народная» историческая травмы: опыт коллективного портрета автора этнонациональных историй Татарстана - Творческая лаборатория историка: горизонты возможного (к 90-летию со дня рождения Б.Г. Могильницкого): материалы Всероссийской научной конференции с международным участием (Томск, 3-4 октября 2019 г.): в 2 ч. Ч. 2. Томск: Изд-во Том. ун-та. С. 358-364.

Овчинников А.В. Одна неделя Рафаэля Сибгатовича. Доступ: http:// lawinrussia.ru/content/odna-nedelya-rafaelya-sibgatovicha (проверено 8.12.2020).

Овчинников А.В., Ершова Г.Н. 2020. 1552 год в сетевом сообществе Татарстана: социальные и политические аспекты версий исторической травмы - Власть. Том. 28. № 4. С. 138-146.

Сагитова Л.В. 2019. Политика идентичности и ее акторы в условиях социальной трансформации в Республике Татарстан: дис. ... д. полит. н. Казань. 428 с. C. 143.

Салагаев А.Л., Сергеев С.А., Лучшева Л.В. 2009. Социокультурный портрет Республики Татарстан: монография. Казань: КГТУ. 128 с. С. 28.

Шанин Т. 2019. Неудобный класс: политическая социология крестьянства в развивающемся обществе: Россия, 1910-1925. М.: Издательский дом «Дело» РАНХИГС. 408 с. 
OVCHINNIKOV Aleksandr Viktorovich, Cand.Sci. (Hist.), Scientific Researcher of the Laboratory of Transdisciplinary Research of Cognition, Language, and Social Practices, Faculty of Philosophy, National Research Tomsk State University (36 Lenina Ave, Tomsk, Russia, 634050; ovchinnikov8_831@mail.ru)

\section{«THE GREAT UNKNOWN» AND THE URBANIZATION FRONTIER (On the Problem Of Socio-Psychological Foundations of the Historical "Trauma of 1552 ")}

Abstract. The author raises the problem of a complex study of ethnically oriented myths about the past and states the importance of analyzing the socio-psychological foundations of the myth on the example of ideas about the capture of Kazan by the troops of Ivan IV in 1552. For the first time in the scientific literature, a comparative study of academic institutions in Kazan and the unique suburban rural Pestrechinsky district of Tatarstan as a main "constructors" and "consumers" of the myth of the historical «trauma of 1552» is conducted. Common elements of social reality are revealed, the specificity of which is caused by urbanization processes and "frontier trauma". In these socio-psychological conditions, the myth of 1552 is an important element of reality, which determines its vitality and complexity of logical deconstructions.

Keywords: «myth of 1552», historical trauma, urbanization, Pestrechinsky district, «frontier trauma». 